\title{
Serine Phosphorylation of Flagellar Proteins Associated with the Motility Activation of Hamster Spermatozoa
}

\author{
Masakatsu Fujinoki ${ }^{1 *}$, Hideki Ohtake ${ }^{2}$ and Makoto Okuno ${ }^{1}$ \\ ${ }^{1}$ Department of Biology, Graduate School of Arts and Science, University of Tokyo, Komaba, Meguro-ku, Tokyo 153-0041, \\ Japan; and ${ }^{2}$ Department of Physiology, Dokkyo University School of Medicine, Mibu, Tochigi 321-0293, Japan \\ (Received 18 January 2001; and accepted 28 February 2001)
}

\begin{abstract}
It has been widely accepted that the motility of spermatozoa is regulated by phosphorylation of flagellar proteins. In order to understand the regulatory mechanisms of the motility of mammalian spermatozoa, we investigated protein phosphorylation associated with motility activation. For precise analyses, we designated four steps in motility activation. They were pre-initiation (immotile spermatozoa), initiation (calcium-independent activation), activation (calcium-dependent activation), and hyperactivation. We detected $66 \mathrm{~K}, 58 \mathrm{~K}$, and $36 \mathrm{~K}$ proteins as the phosphoproteins related to the motility of spermatozoa. Among them, $36 \mathrm{~K}$ proteins were separated into two different isoelectric proteins. When the motility of the spermatozoa was changed from pre-initiation to initiation, which is independent of calcium, $66 \mathrm{~K}$ and $58 \mathrm{~K}$ proteins were exclusively phosphorylated. When the spermatozoa were activated from the initiation by extracellular calcium, two types of $36 \mathrm{~K}$ proteins were phosphorylated. All these proteins were phosphorylated at the serine residues. On the basis of the present results, we propose that the motility of hamster spermatozoa may be regulated through at least two pathways of protein phosphorylation. Proteins of $66 \mathrm{~K}$ and $58 \mathrm{~K}$ are involved in a calcium-independent pathway to initiate the motility of spermatozoa. On the other hand, two types of $36 \mathrm{~K}$ proteins are involved in a calcium-dependent pathway to activate the motile spermatozoa.
\end{abstract}

Extracellular calcium and/or bicarbonate are important and essential components for the motility activation of mammalian spermatozoa $(40,16)$. They stimulate adenylate cyclase to

* Present address: Department of Physiology, Dokkyo University School of Medicine, Mibu, Tochigi 321-0293, Japan

* Corresponding to: Masakatsu Fujinoki

Department of Physiology,

Dokkyo University School of Medicine,

Mibu, Tochigi 321-0293, Japan

Phone: +81-282-87-2125

Fax: +81-282-86-7835

Email: fujinoki@dokkyomed.ac.jp increase the cAMP concentration $(9,20)$. Cyclic AMP activates cAMP-dependent protein kinase resulting in the phosphorylation of proteins. Finally, the interaction between dynein and tubulin is initiated and generates the bending motion in flagella $(15,10)$. In hamster spermatozoa, the extracellular activation factor is calcium (6) and triggers the intracellular signal transduction described above. In these pathways, the signal transduction for the motility activation of spermatozoa is assumed to be a cascade composed of protein phosphorylation. Recently, phosphorylations of many proteins related to motility activation have been detected in several mammalian species. For example, proteins of 175, 93, 44, 40, 
$38,20 \mathrm{k}-\mathrm{Da}$ in boar spermatozoa (11), 45.0, 31.5, $17.2,14.7$ and $13.3 \mathrm{k}-\mathrm{Da}$ in rat spermatozoa (4), $58 \mathrm{k}-\mathrm{Da}$, named axokinin, in canine spermatozoa (29), 120, 82 and $65 \mathrm{k}$-Da in mouse spermatozoa $(23,30), 120,105$ and $81 \mathrm{k}-\mathrm{Da}$ in human spermatozoa $(30,14)$ and $36 \mathrm{k}-\mathrm{Da}$ in hamster spermatozoa (24). Some of them were phosphorylated in a cAMP-dependent manner.

In our previous studies, $36 \mathrm{k}-\mathrm{Da}$ protein obtained from flagella of hamster spermatozoa (24) and 65k-Da protein obtained from flagella of mouse spermatozoa (23) were phosphorylated in a cAMP-dependent manner on activation of the motility of spermatozoa. It was also suggested that the protein of $36 \mathrm{k}-\mathrm{Da}$ protein regulated sliding of the microtubules (24). Therefore, it was likely that both $36 \mathrm{k}-\mathrm{Da}$ and $65 \mathrm{k}-\mathrm{Da}$ proteins were phosphoproteins that regulated the motility activation of spermatozoa. As for flagellar movement, we suggested previously that several steps are required for motility activation in mouse spermatozoa (22). Although an extracellular activation factor is bicarbonate in mouse spermatozoa, the spermatozoa moved slowly in the medium without bicarbonate (23). As for hamster spermatozoa, the similar results were obtained (24). The beat frequency of flagella in hamster spermatozoa increased to $11-13 \mathrm{~Hz}$ when the spermatozoa were activated with calcium, but the flagella of the spermatozoa could still move with a beat frequency of $1-2 \mathrm{~Hz}$ even when calcium was chelated with EGTA. Those observations suggest that extracellular calcium is required for the activation of motility, but unnecessary for motility initiation in hamster spermatozoa.

In this paper, we analyzed changes in protein phosphorylation in relation to motility activation of hamster spermatozoa. We propose that there are at least two types of signal transduction pathways that regulate motility activation of hamster spermatozoa.

\section{MATERIALS AND METHODS}

Reagents. ATP, cAMP and anti-phosphoserine monoclonal antibody (PSR-45) were purchased from Sigma Chemical Company (St. Louis, MO). $\left[\gamma^{-32} \mathrm{P}\right]$-ATP $(3000 \mathrm{Ci} / \mathrm{mmol})$ was purchased from Daiichi Pure Chemical (Tokyo, Japan). Histofine SAB-PO (M) Kit was purchased from Nichirei (Tokyo, Japan). Agarose IEF and ampholine were purchased from AmershamPharmacia Biotech AB (Uppsala, Sweden). Other chemicals were of reagent grade from Wako Pure Chemical Industries, Ltd. (Osaka, Japan).

Animals and preparation of spermatozoa. Sexually mature male golden hamsters (Mesocricetus auratus) were used. Spermatozoa were obtained from the cauda epididymis. The spermatozoa prepared in the present experiments were preinitiated, initiated, activated and hyperactivated.

Two types of the pre-initiated spermatozoa, for back-cross-phosphorylation and for western blotting, were prepared. The pre-initiated spermatozoa for back-cross-phosphorylation were prepared as follows. One volume of cauda epididymal spermatozoa were suspended in 10 volumes of ice-cold homogenization buffer and then homogenized immediately on ice. The homogenization buffer contained $200 \mathrm{mM}$ sucrose, $25 \mathrm{mM}$ glutamic acid, $25 \mathrm{mM} \mathrm{KOH}$ and $20 \mathrm{mM}$ Tris- $\mathrm{HCl}$ (pH 7.9). After homogenization with 100 strokes up and down, most spermatozoa did not move. But a small number of spermatozoa have moved by diluting with the ice-cold homogenization buffer for a brief moment just before completely crushed. The pre-initiated spermatozoa for western blotting were prepared as follows. One volume of cauda epididymal spermatozoa were suspended in 100 volumes of ice-cold pure water and then homogenized immediately. In pure water, they were completely immotile.

The initiated or activated spermatozoa were prepared according to the method described previously (24). Briefly, the initiated spermatozoa were prepared by suspending one volume of cauda epididymal spermatozoa in 100 volumes of isotonic sucrose-EGTA solution containing 310 $\mathrm{mM}$ sucrose, $1 \mathrm{mM}$ EGTA and $10 \mathrm{mM}$ HEPES$\mathrm{NaOH}\left(\mathrm{pH} 7.4\right.$ at $\left.37^{\circ} \mathrm{C}\right)$. The initiated spermatozoa exhibited low beat frequency less than $2 \mathrm{~Hz}$ and progressed a little. Activated spermatozoa were prepared by suspending one volume of cauda epididymal spermatozoa in 100 volumes of isotonic sucrose-calcium solution containing 310 $\mathrm{mM}$ sucrose, $2 \mathrm{mM} \mathrm{CaCl}$, and $10 \mathrm{mM}$ HEPES$\mathrm{NaOH}\left(\mathrm{pH} 7.4\right.$ at $37^{\circ} \mathrm{C}$ ). The initiated or activated sperm suspensions were incubated for $10 \mathrm{~min}$ at $37^{\circ} \mathrm{C}$. After incubation, spermatozoa exhibited approximately $90 \%$ motility were used in the experiment.

The hyperactivated spermatozoa were prepared according to the method described previously (25) with modified Tyrode's albumin lactate pyruvate (m-TALP) medium (17) containing 
$101.02 \mathrm{mM} \mathrm{NaCl}, 2.68 \mathrm{mM} \mathrm{KCl}, 2.00 \mathrm{mM} \mathrm{CaCl}_{2}$, $1.50 \mathrm{mM} \mathrm{MgCl} \mathrm{M}_{2}-6 \mathrm{H}_{2} \mathrm{O}, 0.36 \mathrm{mM} \mathrm{NaH} \mathrm{PO}_{4}-2 \mathrm{H}_{2} \mathrm{O}$, $35.70 \mathrm{mM} \mathrm{NaHCO}$, $4.50 \mathrm{mM}$ D-glucose, $0.09 \mathrm{mM}$ sodium pyruvate, $9.00 \mathrm{mM}$ sodium lactate, 0.50 $\mathrm{mM}$ hypotaurine, $0.05 \mathrm{mM}$ (-)epinephrine, 0.20 $\mathrm{mM}$ sodium taurochoric acid, $5.26 \mu \mathrm{M}$ sodium metabisulfite, $0.05 \%(\mathrm{w} / \mathrm{v})$ streptomycin sulfate, $0.05 \%(\mathrm{w} / \mathrm{v})$ potassium penicillin $\mathrm{G}$ and $15 \mathrm{mg} /$ $\mathrm{mL} \mathrm{BSA}\left(\mathrm{pH} 7.4\right.$ at $37^{\circ} \mathrm{C}$ under $5 \% \mathrm{CO}_{2}$ in air). An aliquot (about $10 \mu \mathrm{L}$ ) of cauda epididymal spermatozoa was placed on the bottom of a test tube. Several $\mathrm{mL}$ of the m-TALP medium was then carefully added and overlayed with mineral oil. They were incubated for $10 \mathrm{~min}$ to allow the activated spermatozoa to swim up. The supernatant containing the highly motile spermatozoa was collected, placed on the culture plate, covered with mineral oil and incubated for $3 \mathrm{~h}$ at $37^{\circ} \mathrm{C}$ under $5 \% \mathrm{CO}_{2}$ in air. Spermatozoa exhibited approximately $80 \%$ hyperactivated motility were used in the experiment.

Preparation of demembranated flagella of the spermatozoa. Demembranated flagella of the spermatozoa were prepared from the pre-initiated, initiated, activated and hyperactivated spermatozoa according to the method described previously (23) with some modifications. Each prepared sperm suspension was centrifuged at $5,500 \times g$ for 5 min at $4{ }^{\circ} \mathrm{C}$. Spermatozoa pelleted were suspended in 100-fold volume of the above homogenization buffer (see Animals and preparation of spermatozoa). After centrifugation at $750 \times g$ for 5 min at $4{ }^{\circ} \mathrm{C}$, the precipitate was resuspended in a 20 -fold volume of the homogenization buffer supplemented with $2 \mathrm{mM}$ PMSF and $20 \mu \mathrm{g} / \mathrm{mL}$ leupeptine. The suspension was homogenized with 100 strokes to remove flagella from heads with a Teflon homogenizer. The homogenate was then diluted into a 4-fold volume of the homogenization buffer supplemented with $0.5 \mathrm{mM}$ PMSF and $5 \mu \mathrm{g} / \mathrm{mL}$ leupeptine. After centrifugation at $750 \times g$ for $5 \mathrm{~min}$ at $4{ }^{\circ} \mathrm{C}$, the supernatant was collected and centrifuged at $5,500 \times g$ for $5 \mathrm{~min}$ at $4{ }^{\circ} \mathrm{C}$. The precipitate, which contained isolated flagella, was suspended in a 20 -fold volume of the demembranation buffer containing $200 \mathrm{mM}$ sucrose, $25 \mathrm{mM}$ glutamic acid, $25 \mathrm{mM} \mathrm{KOH}, 1 \mathrm{mM}$ DTT, $0.1 \%(\mathrm{w} / \mathrm{v})$ Triton $\mathrm{X}-100$ and $20 \mathrm{mM}$ Tris- $\mathrm{HCl}(\mathrm{pH} 7.9)$ and incubated for $30 \mathrm{~s}$ at ambient temperature. The flagellar suspension was centrifuged at $5,500 \times g$ for $5 \mathrm{~min}$ at $4{ }^{\circ} \mathrm{C}$. Protein concentration of pelleted flagella was determined using the method of Bradford (2) and was adjusted to a final protein concentration of 1 $\mathrm{mg} / \mathrm{mL}$ with the homogenization buffer.

Dissolution of demembranated flagella of the spermatozoa. Dissolution of demembranated flagella of the spermatozoa was performed according to the method of Hirabayashi (8) with some modifications. Tri-chloroacetic acid (TCA) was added to the suspension of demembranated flagella to a final concentration of $10 \%(\mathrm{w} / \mathrm{v})$. The suspension was centrifuged at $15,000 \times g$ for $20 \mathrm{~min}$ at $4{ }^{\circ} \mathrm{C}$. The precipitate was rinsed with a 10 -fold volume of ice-cold acetone for three times, resuspended at $10 \mathrm{mg} / \mathrm{mL}$ in a guanidine solution containing $8 \mathrm{M}$ guanidine hydrochroride, $10 \mathrm{mM}$ sodium pyrophosphate, $10 \%$ (v/v) 2mercaptoethanol, $2 \%(\mathrm{v} / \mathrm{v})$ Nonidet P-40 (NP-40) and $0.5 \mathrm{M}$ Tris- $\mathrm{HCl}(\mathrm{pH} 7.5)$ and dialysed against a urea solution containing $7 \mathrm{M}$ urea and $1 \%(\mathrm{v} /$ v) 2-mercaptoethanol. After centrifugation at $15,000 \times \mathrm{g}$ for $20 \mathrm{~min}$ at $4{ }^{\circ} \mathrm{C}$, absorbance of the supernatant was measured at $280 \mathrm{~nm}$.

Gel electrophoresis. SDS-PAGE was carried out according to the method of Laemmli (13). The separating gel used was $10 \%(\mathrm{w} / \mathrm{v})$ polyacrylamide containing $0.1 \%(\mathrm{w} / \mathrm{v})$ SDS.

Two-dimensional gel electrophoresis combined with agarose isoelectric focusing (agarose IEF) and SDS-PAGE was carried out according to the method of Hirabayashi (8) with some modifications. A pre-blended ampholine ( $\mathrm{pH} 3.5-9.5)$ or

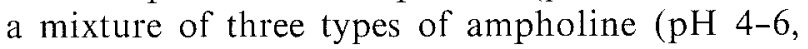
$\mathrm{pH} 6-8$ and $\mathrm{pH} 3.5-10$ used at $4: 2: 3$ ) was used as a carrier ampholite. SDS-PAGE as the second dimension was carried out as described above.

Sucrose density gradient isoelectric focusing (sucrose density gradient IEF). Sucrose density gradient IEF was carried out according to the method of Vesterberg (33) with some modifications. Sucrose density gradient was made from 0 to $50 \%(\mathrm{v} / \mathrm{v})$ together with an ampholine $(\mathrm{pH}$ $3.5-10)$ as the carrier ampholite. To all solutions were added $3 \mathrm{M}$ urea as a final concentration. After electrophoresis, the sucrose density gradient solution was collected in fractions of $2 \mathrm{~mL}$. Absorbance of $580 \mathrm{~nm}$ and $\mathrm{pH}$ in each fraction were determined.

Preparation of protein from polyacrylamide gel. After electrophoresis and stain, spots of detected 
proteins were cut out from polyacrylamide gel. The spots of proteins were homogenized in the gel extract solution containing $1 \%(\mathrm{w} / \mathrm{v})$ SDS, $10 \%$ (v/v) Glycerol, $5 \mathrm{mM}$ 2-mercaptoetanol and 10 $\mathrm{mM}$ Tris- $\mathrm{HCl}$ (pH8.0). Extracts were dialysed against the same solution at $4{ }^{\circ} \mathrm{C}$ for $24 \mathrm{~h}$. After centrifugation at $15,000 \times g$ for $5 \mathrm{~min}$ at $4{ }^{\circ} \mathrm{C}$, the supernatant was concentrated with molcut LGC ultrafiltration (Millipore Corp., Bedford, MA) and used as protein extracts.

Back-cross-phosphorylation. The procedure for investigating the incorporation of inorganic phosphate into the flagellar proteins was based on the method described previously (23) with some modifications. Cauda epididymis spermatozoa were suspended to each medium and incubated (see animal and preparation of spermatozoa). Then, demembranated sperm flagella were prepared (see Preparation of demembranated flagella of the spermatozoa). Demembranated sperm flagella were incubated for $30 \mathrm{sec}$ at room temperature in the reactivation solution containing 200 $\mathrm{mM}$ sucrose, $25 \mathrm{mM}$ glutamic acid, $25 \mathrm{mM} \mathrm{KOH}$, $1 \mathrm{mM} \mathrm{MgSO}_{4}, 20 \mathrm{mM}$ Tris- $\mathrm{HCl}(\mathrm{pH} 7.9), 0.5 \mu \mathrm{M}$ cAMP, $1 \mathrm{mM}$ ATP and $3.7 \mathrm{MBq}\left[\gamma^{32} \mathrm{P}\right]$-ATP $(3000 \mathrm{Ci} / \mathrm{mM})$. The protein concentration was adjusted to $400 \mu \mathrm{g} / \mathrm{mL}$. The reactivation was terminated by the addition of TCA to a final concentration of $10 \%(\mathrm{w} / \mathrm{v})$ followed by centrifugation at $15,000 \times g$ for $10 \mathrm{~min}$ at $4{ }^{\circ} \mathrm{C}$. The precipitate was washed with a 10 -fold volume of ice-cold methanol for three times. After washing, the precipitate was resuspended in 10fold volume of the urea-NP-40 solution containing $5 \mathrm{M}$ urea, $1 \mathrm{M}$ thiourea, $10 \mathrm{mM}$ sodium pyrophosphate and $2 \%(\mathrm{v} / \mathrm{v}) \mathrm{NP}-40$. After sonication for $30 \mathrm{~min}$ on ice, the resuspension was centrifuged at $15,000 \times \mathrm{g}$ for $5 \mathrm{~min}$ at $4{ }^{\circ} \mathrm{C}$. The supernatant was subjected to two-dimensional gel electrophoresis. The stained gel was exposed to Kodak XAR-5 film (Eastman-Kodak, Rochester, NY) backed with Crone intensifying screens (Wilmington, DE) for 5 days at $-80^{\circ} \mathrm{C}$. In some experiments, ${ }^{32} \mathrm{P}$-labeled proteins were quantified by densitometry with a NIH Image. Density surrounding each protein spot was used as background. The value that removed the density of background from the density of each protein spot was used to determine quantity of each protein spots.

Western blotting. Western blotting was based on the method of Towbin et al. (31). The blotted membrane was blocked with $5 \%(\mathrm{w} / \mathrm{v})$ BSA in TBS (Tris buffered saline) containing $0.15 \mathrm{M}$ $\mathrm{NaCl}$ and $20 \mathrm{mM}$ Tris- $\mathrm{HCl}(\mathrm{pH} \mathrm{7.5)}$ for $1 \mathrm{~h}$ at $20^{\circ} \mathrm{C}$, and incubated with anti-phospho amino acid antibody (1:1000 dilution with $5 \%(\mathrm{w} / \mathrm{v})$ BSA in TBS) for $1 \mathrm{~h}$ at $20^{\circ} \mathrm{C}$. Color reaction was carried out with a Histofine SAB-PO (M) Kit and $\mathrm{H}_{2} \mathrm{O}_{2}$ and DAB (3, 3'-diaminobenzidine tetrahydrochloride) as the substrate for peroxidase. In some experiments, reacted antibodies were quantified by densitometry with a NIH Image as described above (see back-cross-phosphorylation).

Mass spectrometry. Protein samples extracted from polyacrylamide gel were desalted by HiTrap Desalting (Amersham-Pharmacia Biotech AB, Uppsala, Sweden) or by the inverse gradient reverse phase chromatography $(27,28)$ using $\mu \mathrm{RPC}$ C18 column set on SMART system (Amersham-Pharmacia Biotech AB, Uppsala, Sweden). Gradient of 95-50\% n-propanol was carried out using $95 \% \mathrm{n}$-propanol and mixture of $50 \%$ n-propanol and $0.05 \%$ TFA. After chromatography, all fractions were subjected to mass spectrometry, MALDI-TOF-MASS (Voyager-DE STR, PerSeptive Biosystems, Inc., Framingham, MA) in order to examine molecular mass and purity of proteins.

Peptide digestion. After electrophoresis, spots were cut out from polyacrylamide gel and subjected to the in-gel-digestion (12) using AP1 and V8 protease. After digestion, the resultants were subjected to the SMART system with reverse phase chromatogram using sephasil C18 column. Gradient of $0-100 \%$ acetonitoril was prepared with $0.01 \%$ TFA and the mixture of $0.01 \%$ TFA and $100 \%$ acetonitoril for extraction. After the chromatography, all fractions were subjected to mass spectrometry using MALDI-TOF-MASS in order to determine molecular mass and to examine purity of peptides.

Amino acid sequence. Amino acid sequence analysis for prepared peptides was done with a Peptide Sequencer (PPSQ-21, Shimazu Co. Ltd., Kyoto). 


\section{RESULTS}

Detection of phosphorylated proteins associated with the motility activation of spermatozoa

We demonstrated previously that the hamster spermatozoa moved slowly even when extracellular calcium was chelated, and that the spermatozoa swam actively when calcium was present in the medium (24). This observation suggests that extracellular calcium is not necessarily required to initiate hamster sperm motility. In order to examine successive changes in protein phosphorylation related to motility initiation and activation, we prepared completely immotile spermatozoa in the present experiments together with three kinds of spermatozoa in different motility as prepared in the previous works. We then redefined motility of spermatozoa as preinitiation (Fig. 1a and lb), initiation (Fig. Ic and 1d), activation (Fig. le and 1f) and hyperactivation (Fig. $1 \mathrm{~g}$ and $\mathrm{lh}$ ). The immotile spermatozoa observed on dilution into the pure water were referred to as pre-initiated spermatozoa. Spermatozoa that exhibited slow movement in the absence of calcium were referred to as initiated spermatozoa. Activated spermatozoa moved progressively with high beat frequency. A hyperactivated spermatozoon occurred during passage though the female reproductive tract and exhibited large bend amplitude. We therefore redefined the "motility initiation" of the spermatozoa as the step from pre-initiation to the initiation. Motility activation of the spermatozoa was redefined as the change from initiation to activation. In order
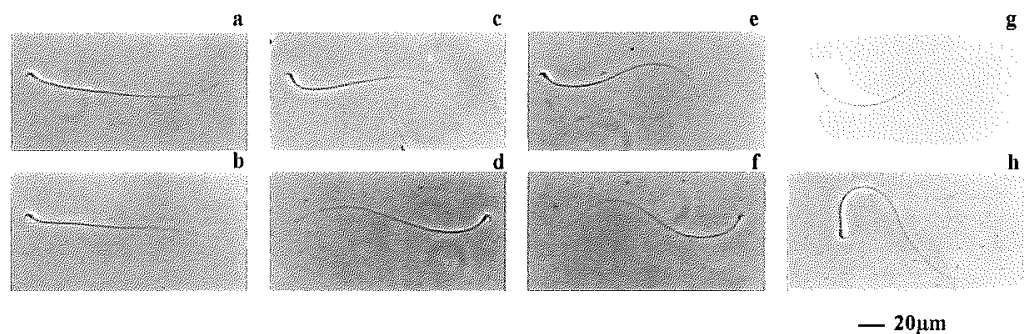

Fig. 1 Pattern of Flagellar bending of spermatozoa. Pre-initiated spermatozoa (a and b), initiated spermatozoa (c and d), activated spermatozoa (e and f) and hyperactivated spermatozoa ( $\mathrm{g}$ and $\mathrm{h}$ ) are shown. Scale bar is $20 \mu \mathrm{m}$.

Table 1 Phosphorylation changes from pre-initiation to activation via initiation

A: Comparison of activation and pre-initiation (from Fig. 3)

\begin{tabular}{ccc}
\hline Protein & $\begin{array}{c}\text { Activation } \\
\text { (means } \pm \text { S.D., } \mathrm{n}=4)\end{array}$ & $\begin{array}{c}\text { Pre-initiation } \\
\text { (means } \pm \text { s.D., } \mathrm{n}=4)\end{array}$ \\
\hline $66 \mathrm{~K}$ & N.D. & $64.56 \pm 1.48$ \\
$58 \mathrm{~K}$ & N.D. & $71.61 \pm 1.11$ \\
$36 \mathrm{~K}-\mathrm{B}$ & $13.34 \pm 1.17$ & $52.87 \pm 3.34^{*}$ \\
\hline
\end{tabular}

* mark; $P<0.01$ compared with activation.

B: Comparison of activation and initiation (from Fig. 4)

\begin{tabular}{ccc}
\hline Protein & $\begin{array}{c}\text { Activation } \\
\text { (means } \pm \text { S.D. }, \mathrm{n}=4)\end{array}$ & $\begin{array}{c}\text { Initiation } \\
\text { (means } \pm \text { s.D., } \mathrm{n}=4)\end{array}$ \\
\hline $66 \mathrm{~K}$ & N.D. & N.D. \\
$58 \mathrm{~K}$ & N.D. & N.D. \\
$36 \mathrm{~K}-\mathrm{A}$ & N.D. & $32.06 \pm 3.31$ \\
$36 \mathrm{~K}-\mathrm{B}$ & $15.52 \pm 3.62$ & $40.28 \pm 2.69^{*}$ \\
\hline
\end{tabular}

*mark; $P<0.01$ compared with activation. 
to understand the mechanisms that regulate beginning of flagellar movement, we especially focused on changes from pre-initiation to activation via initiation in this paper.

We first examined protein phosphorylation associated with motility activation of the spermatozoa by back-cross-phosphorylation with $\left[\gamma^{-32}\right.$ P]-ATP (Fig. 2). It was suggested that protein phosphorylation occurred at motility activation of spermatozoa (40). Therefore, flagellar proteins related to the regulation of motility activation were phosphorylated using ATP of spermatozoa when spermatozoa activated. When activated sperm flagella were demembranated and subject- ed to back-cross-phosphorylation, small amounts of or no ${ }^{32} \mathrm{P}$ should be incorporated into flagellar proteins related to the regulation of motility activation in incubation with $\left[\gamma^{-32} \mathrm{P}\right]$-ATP together with cAMP (within $30 \mathrm{~s}$ ) since the flagellar proteins were already phosphorylated. On the other hand, proteins related to the regulatory mechanism of motility activation were not phosphorylated in pre-initiated spermatozoa. Therefore, large amounts of ${ }^{32} \mathrm{P}$ should be incorporated into those proteins when pre-initiated spermatozoa were subjected to back-cross-phosphorylation. As shown in Fig. 3 and Table 1A, three phosphoproteins were detected as phosphorylated

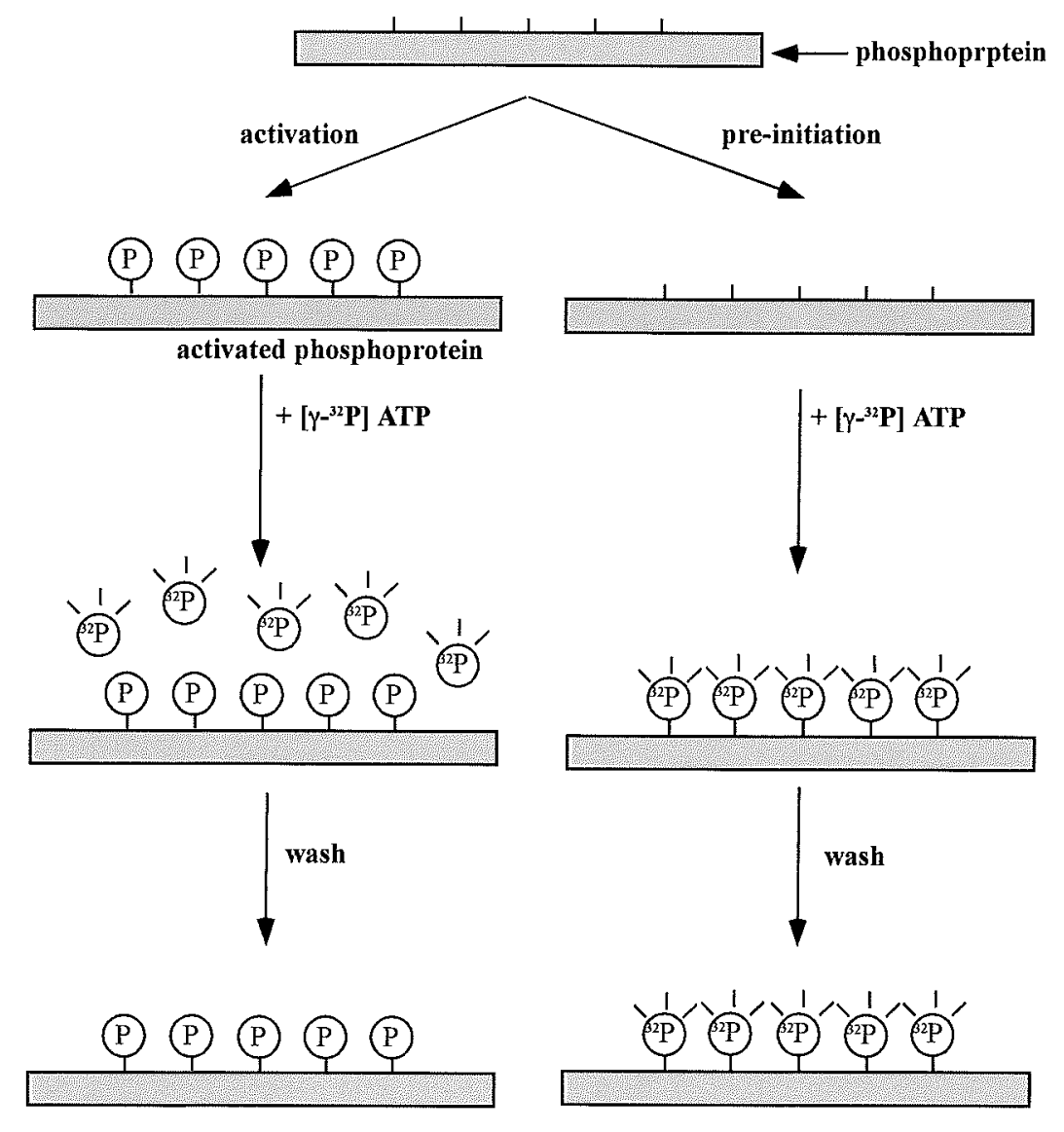

Fig. 2 The principles of back-cross-phosphorylation. When spermatozoa were demembranated and suspended to the reactivation solution containing $\left[\gamma_{-}{ }^{32} \mathrm{P}\right]$-ATP (see back-cross-phosphorylation) and incubated, many proteins were phosphorylated. In immotile spermatozoa, phosphoproteins related to the motility activation were not phosphorylated yet, while the phosphoproteins in activated spermatozoa were already phosphorylated. Therefore, small amounts of or no ${ }^{32} \mathrm{P}$ should be incorporated into the phosphoproteins (Left) in activated spermatozoa since the phosphoproteins were already phosphorylated. On the other hand, in pre-initiated spermatozoa, large amounts of ${ }^{32} \mathrm{P}$ should be incorporated into the phosphoproteins (Right) since the phosphoproteins were not phosphorylated. 
proteins associated with motility activation of spermatozoa. Three proteins were designated as $66 \mathrm{~K}, 58 \mathrm{~K}$ and $36 \mathrm{~K}$ proteins from approximately molecular weight.

For the next step, we studied protein phosphorylation occurring between initiation and activation (Fig. 4 and Table 1B). Only two kinds of $36 \mathrm{~K}$ proteins, 36K-A (acidic side spot) and $36 \mathrm{~K}-$ $\mathrm{B}$ (basic side spot) protein, were phosphorylated. Both $36 \mathrm{~K}-\mathrm{A}$ and $36 \mathrm{~K}-\mathrm{B}$ proteins were equivalent in molecular weight, but different in pI value. The spot of $36 \mathrm{~K}$ protein detected in Fig. 3 was assumed to be $36 \mathrm{~K}-\mathrm{B}$ protein in Fig. 4. Comparing phosphorylation in Fig. 3 with that in Fig. 4, incorporation of $\gamma^{32} \mathrm{P}$ into $36 \mathrm{~K}-\mathrm{B}$ protein of pre-initiated spermatozoa was significantly stron- ger than that of initiated one (Table $1 \mathrm{~B}$ and $\mathrm{C}$ ). Therefore, it was likely that $36 \mathrm{~K}-\mathrm{B}$ protein was gradually phosphorylated on motility initiation and activation. Phosphorylation of $36 \mathrm{~K}-\mathrm{A}$ protein appeared in only initiated spermatozoa (Fig. $4 \mathrm{C}$ compared with Fig. 3C).

Feature in phosphorylation of four phosphoproteins occurring from pre-initiation to hyperactivation via activation

We tried to detect phosphorylated proteins in the flagella of spermatozoa by Western blotting with anti-phospho-amino acid monoclonal antibodies. As shown in Fig. 5 and Table 2A, all phosphoproteins detected in Fig. 3 and 4 (66K,

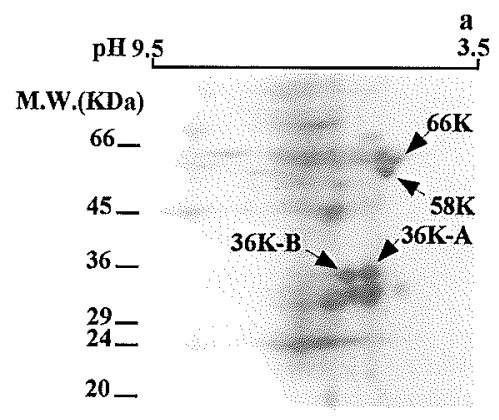

b

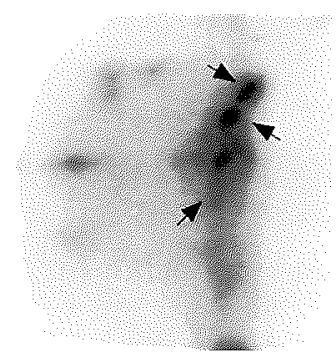

Fig. 3 Back-cross-phosphorylation of flagella of activated and pre-initiated spermatozoa on two-dimensional gel-electrophoresis. IEF gel was done at a $\mathrm{pH}$ range of 3.5-9.5. Protein stain (a), activated spermatozoa (b), pre-initiated spermatozoa (c) are shown. Arrowheads in (c) indicate phosphoproteins associated with motility. Bars on the left side of (a) show molecular weight standards. Statistical analyses of duplicate back-cross-phosphorylation are shown in Table 1A.
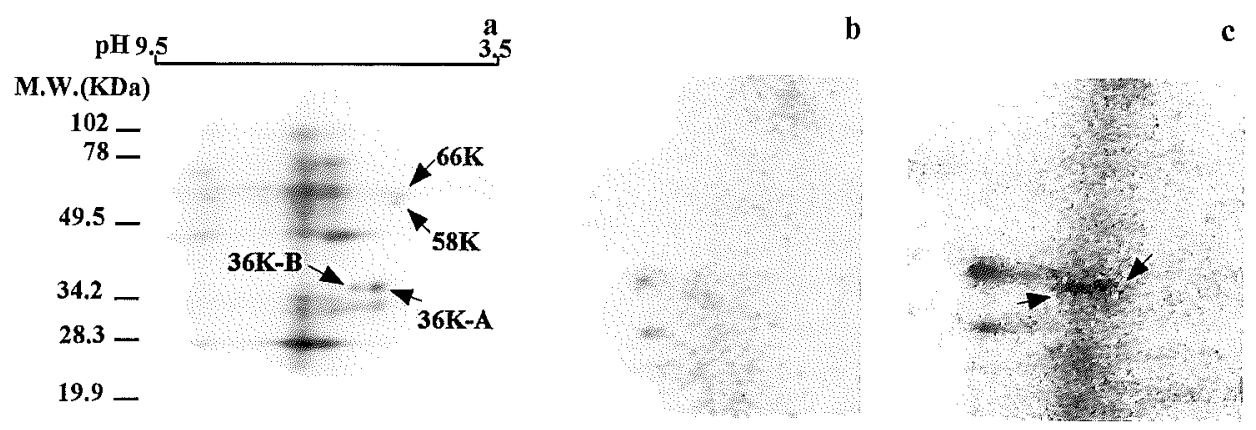

Fig. 4 Back-cross-phosphorylation of flagella of activated and initiated spermatozoa on two-dimensional gel-electrophoresis. IEF gel was performed in a $\mathrm{pH}$ range of 3.5-9.5. Protein stain (a), activated spermatozoa (b), initiated spermatozoa (c) are shown. Arrowheads in (c) indicate phosphoproteins associated with motility. Bars on the left side of (a) show molecular weight standards. Statistical analyses of duplicate back-cross-phosphorylation are shown in Table 1B. 
$58 \mathrm{~K}, 36 \mathrm{~K}-\mathrm{A}$ and $36 \mathrm{~K}-\mathrm{B}$ protein) reacted with anti-phosphoserine antibody. However, they did not react with anti-phosphotyrosine antibody or anti-phosphothreonine antibody (data not shown). In addition, we found that $58 \mathrm{~K}, 36 \mathrm{~K}-\mathrm{A}$ and $36 \mathrm{~K}-\mathrm{B}$ proteins were phosphorylated in the flagella of the activated spermatozoa, but not in those of pre-initiated spermatozoa. Although $66 \mathrm{~K}$ protein had been already phosphorylated in the flagella of the pre-initiated spermatozoa, degrees of phosphorylation increased significantly when the spermatozoa became activated (Table 2A).

Phosphorylation of these four proteins on hyperactivation was also examined. In order to introduce hyperactivation in the spermatozoa, $\mathrm{m}$-TALP medium was employed. The spermatozoa that swam up after 10 min incubation in the m-TALP medium were used as activated spermatozoa. Hyperactivated spermatozoa were obtained after $3 \mathrm{~h}$ incubation in the m-TALP medium. As shown in Figs. 5c and 6b, patterns of protein phosphorylation detected with anti-phosphoserine antibody in the flagella of the spermatozoa activated by the m-TALP medium were the same as those in the flagella of the activated spermatozoa. When the spermatozoa were hyperactivated,

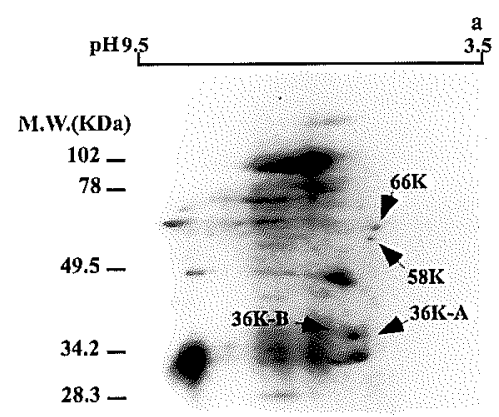

b

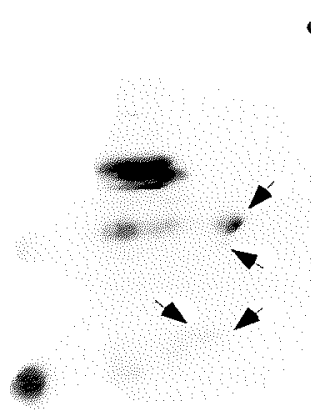

Fig. 5 Serine phosphorylation in flagella of pre-initiated and activated spermatozoa on two-dimensional gel-electrophoresis. IEF gel was performed in a pH range of 3.5-9.5. Protein stain (a), pre-initiated spermatozoa (b), activated spermatozoa (c) and negative control (d) are shown. Arrowheads indicate phosphoproteins associated with motility. Bars on the left side of (a) show molecular weight standards. Statistical analyses of duplicate western blotting are shown in Table $2 \mathrm{~A}$.

Table 2 Serine phosphorylation changes from pre-initiation to hyperactivation via activation

A: Comparison of activation and pre-initiation (from Fig. 5)

\begin{tabular}{ccc}
\hline Protein & $\begin{array}{c}\text { Pre-initiation } \\
\text { (means } \pm \text { s.D., } \mathrm{n}=4)\end{array}$ & $\begin{array}{c}\text { Activation } \\
\text { (means } \pm \text { s.D., } \mathrm{n}=4)\end{array}$ \\
\hline $66 \mathrm{~K}$ & $65.18 \pm 2.8$ & $114.6 \pm 5.88^{*}$ \\
$58 \mathrm{~K}$ & N.D. & $38.64 \pm 4.07$ \\
36K-A & N.D. & $29.97 \pm 1.62$ \\
36K-B & N.D. & $43.45 \pm 1.86$
\end{tabular}

* mark; $P<0.01$ compared with pre-initiation.

B: Comparison of m-TALP activation and hyperactivation (from Fig. 6)

\begin{tabular}{ccc}
\hline Protein & $\begin{array}{c}\text { m-TALP activation } \\
\text { (means } \pm \text { s.D., } \mathrm{n}=4)\end{array}$ & $\begin{array}{c}\text { Hyperactivation } \\
\text { (means } \pm \text { s.D., } \mathrm{n}=4)\end{array}$ \\
\hline $66 \mathrm{~K}$ & $60.05 \pm 2.84$ & $68.88 \pm 3.06^{*}$ \\
$58 \mathrm{~K}$ & $61.31 \pm 4.3$ & $80.33 \pm 1.85^{*}$ \\
36K-A & $62.49 \pm 2.61$ & $65.61 \pm 3.46$ \\
36K-B & $59.76 \pm 2.36$ & $64.13 \pm 2.58^{*}$
\end{tabular}

*mark; $P<0.01$ compared with m-TALP activation. 
four phosphoproteins, $66 \mathrm{~K}, 58 \mathrm{~K}, 36 \mathrm{~K}-\mathrm{A}$ and $36 \mathrm{~K}-\mathrm{B}$, were kept phosphorylated at serine residues (Fig. $6 \mathrm{~b}$ and c). Degrees of phosphorylation of them, except $36 \mathrm{~K}-\mathrm{A}$ protein, markedly increased on hyperactivation (Table $2 \mathrm{~B}$ ).

Mass spectrometry and amino acid sequences of phosphoproteins

Flagellar proteins were isolated by sucrose density gradient IEF (Fig. 7A). Acidic-fractions (from $\mathrm{pH} 5$ to 6) were collected, and separated further by two-dimensional electrophoresis with agarose-IEF (the pH range was about 4-6) (Fig. 7B). Spots of three phosphoproteins were extracted from polyacrylamide gel and then subjected to the inverse gradient reverse phase chromatography. As shown in Fig. 8A, B and C, 66K and two types of $36 \mathrm{~K}$ protein were separated. Each fractions included those three phosphoproteins were analyzed by the mass spectrometry in order to examine molecular mass and purity of them (Fig. 8D, E and F). Each protein occurred as a single component. Mass of $66 \mathrm{~K}, 36 \mathrm{~K}-\mathrm{A}$ and $36 \mathrm{~K}-\mathrm{B}$ proteins were $71,184 \pm 321,36,897 \pm 231$ and $36,443 \pm 262$ respectively.

$58 \mathrm{~K}$ protein spot was subjected to desalting column after extraction from the polyacrylamide gel. $58 \mathrm{~K}$ protein was purified as a single component as shown in Fig. 9A. Thus, the protein was performed to mass spectrometry. As shown in Fig. 9B, 58K protein was submitted as a single peak of $55,615 \pm 136$.

Then, fifteen amino acid residues at the $\mathrm{N}$ terminal region of $58 \mathrm{~K}$ protein were determined. The amino acid sequence obtained was
MQQTEYCCCCCATDQ. Homology search analyses of this sequence showed $46 \%$ homology to human tyrosine kinase (TXK). In order to examine internal amino acid sequences of $58 \mathrm{~K}$ protein, it was subjected to the in-gel-digestion with AP1 and V8 protease. After digestion, peptides were separated by reverse phase chromatography (Fig. 10A). All fractions obtained were performed to mass spectrometry. As shown in Fig. 10B and C, peptides in fraction 33 and 34 were submitted as a single speaks. An amino acid sequence of peptide in fraction 33 was AYPVAPNAGKAVPNE and mass of it was $1451 \pm 2.8$. Theoretical mass of this peptide was 1478. An amino acid sequence of Peptide in fraction 34 was APNYDNIALKAPK and mass of it was approximately $1993 \pm 2.1$. Theoretical mass of this peptide was 1396. Homology search analyses of those two peptides did not show homology to TXK.

\section{DISCUSSION}

Protein phosphorylation has been thought to play important roles in signal transduction pathways that regulate motility activation of spermatozoa $(5,8,16,40)$, but the relationships between protein phosphorylation and activation states of sperm motility are not yet well understood.

Motility activation of mammalian spermatozoa usually goes through three stages, immotile, activated and hyperactivated. The activation is triggered by extracellular activation factor(s), such as calcium and/or bicarbonate $(6,16,20$, $40)$. In our previous reports $(23,24)$, however, we suggested that mammalian spermatozoa were able

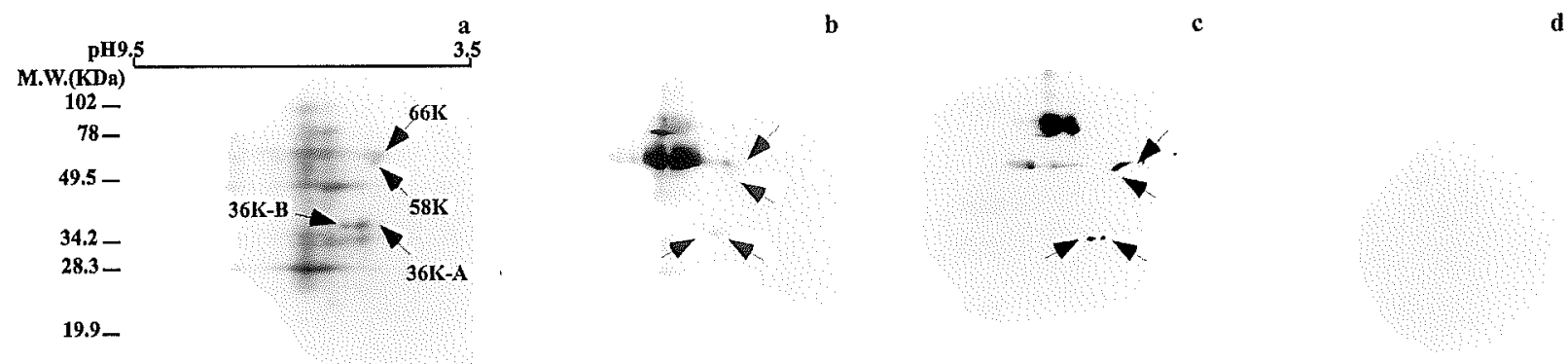

Fig. 6 Serine phosphorylation in flagella of m-TALP activated and the hyperactivated spermatozoa on two-dimensional gel-electrophoresis. IEF gel was performed in a $\mathrm{pH}$ range of 3.5-9.5. Protein stain (a), m-TALP activated spermatozoa (b), hyperactivated spermatozoa (c) and negative control (d) are shown. Arrowheads indicate phosphoproteins associated with motility. Bars on the left side of (a) show molecular weight standards. Statistical analyses of duplicate western blotting are shown in Table 2B. 
to move slowly when suspended in media lacking calcium and/or bicarbonate. In addition, we demonstrated that motility activation of mouse spermatozoa involved multiple steps (22). Therefore, we redefined the flagellar movements as pre-initiation, initiation, activation and hyperactivation. The pre-initiated spermatozoa are immotile. Initiated spermatozoa move slowly and exhibit $1-2 \mathrm{~Hz}$ in beat frequency (24). Activated spermatozoa swim progressively and exhibit 11$13 \mathrm{~Hz}$ in beat frequency (24). Hyperactivated spermatozoa swim with large amplitude of bend (40). We have been investigating protein phospho- rylations corresponding to these four activation states.

In the present experiment, we focused in particular on changes from pre-initiation to activation via initiation in order to understand the mechanisms that regulate the beginning of flagellar movement. As shown in the present experiments (see Figs. 3 and 4), we have detected at least four phosphoproteins involved in motility activation, $66 \mathrm{~K}, 58 \mathrm{~K}, 36 \mathrm{~K}-\mathrm{A}$ and $36 \mathrm{~K}-\mathrm{B}$ protein.

The present study demonstrated that the $36 \mathrm{k}-$ Da protein reported in the previous study (24) included $36 \mathrm{~K}-\mathrm{A}$ and $36 \mathrm{~K}-\mathrm{B}$ protein. The two
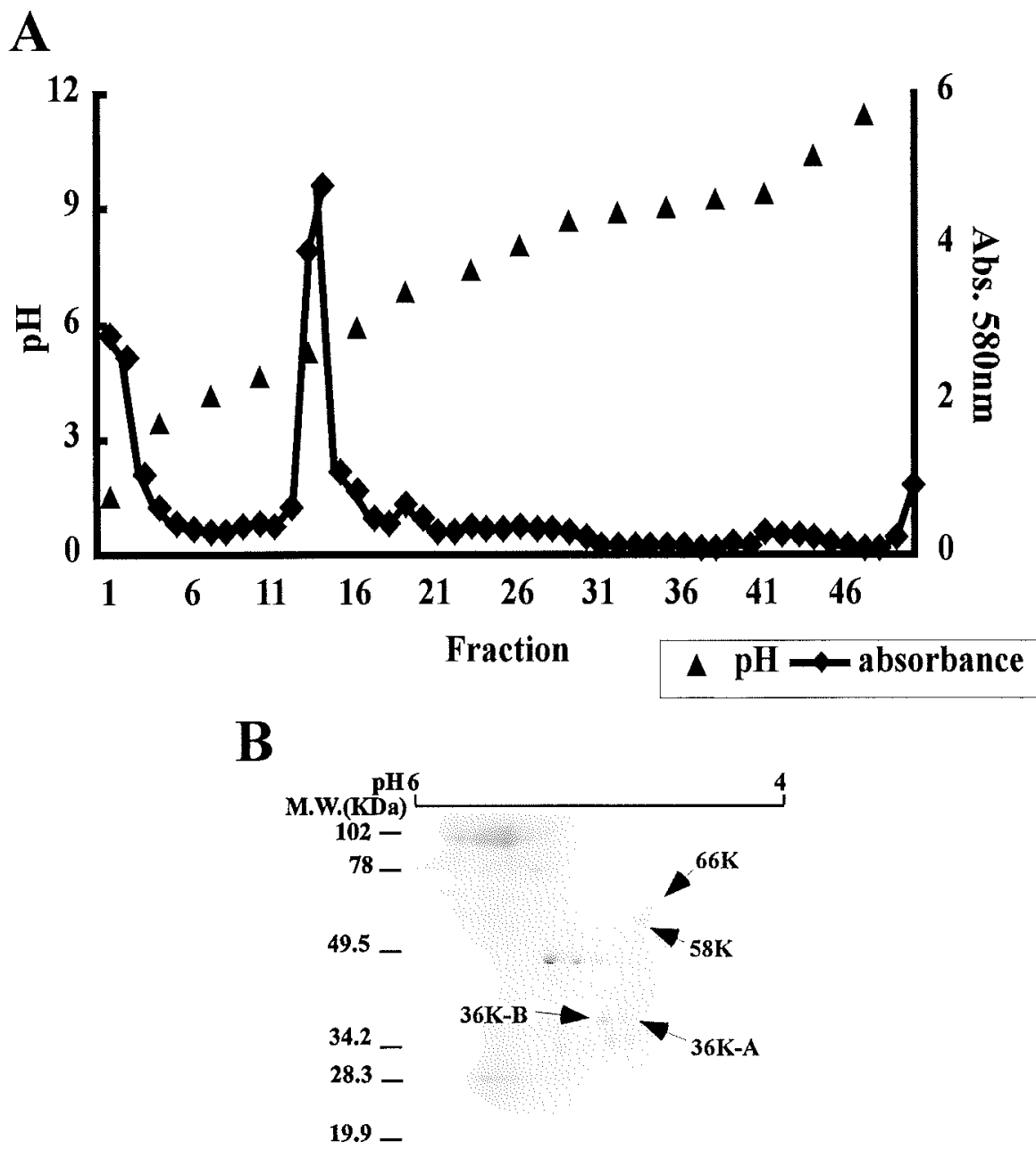

Fig. 7 Preparation of phosphoproteins associated with motility using electrophoresis. A: Sucrose density gradient IEF of flagellar extracts. After sucrose density gradient IEF and fractionation, the $\mathrm{pH}$ and the absorbance of $580 \mathrm{~nm}$ of each fraction were measured. Most proteins were recovered in acidic $\mathrm{pH}$ fractions, fraction 13,14 and 15 which $\mathrm{pH}$ was from $\mathrm{pH} 4.5$ to $\mathrm{pH}$ 6. B: Two-dimensional gel-electrophoresis of fractions recovered from sucrose density gradient IEF. IEF gel was performed at a $\mathrm{pH}$ range of 4-6. Arrowheads indicate phosphoproteins associated with motility. Bars on the left side show molecular weight standards. 
proteins were strongly phosphorylated when the flagellar motility changed from the initiated state to the activated state (see Figs. 3 and 4, and Table 1). Especially, phosphorylation of $36 \mathrm{~K}$-A protein was associated more closely with the change from initiation to activation since it was detected only in back-cross-phosphorylation of initiated spermatozoa. A kinase responsible for phosphorylation of $36 \mathrm{~K}-\mathrm{A}$ protein seemed to be activated only when spermatozoa began to move. On the other hand, both $66 \mathrm{~K}$ and $58 \mathrm{~K}$ proteins were phosphorylated when the motility of spermatozoa changed from pre-initiation to initiation (see Figs. 3 and 4, and Table 1). It was therefore likely that phosphorylations of $66 \mathrm{~K}$ and $58 \mathrm{~K}$ proteins are closely associated with motility initiation.

It has been reported widely that tyrosine phosphorylation is a part of main signal cascade in mammalian sperm capacitation $(11,35,36,38)$. As for the phosphorylation of flagellar protein at tyrosine residues, AKAP (A-kinase Anchor Protein), which binds to the RII subunit of A-kinase, has been reported $(3,19,34,37)$. We demonstrated previously that flagellar protein of $80 \mathrm{k}-\mathrm{Da}$ was phosphorylated at tyrosine residues on hyperactivation $(25,26)$. In trout and salmon spermatozoa, $15 \mathrm{~K}$ protein was detected as a tyrosine phosphorylated protein that regulates the initiation of the sperm motility (18). From the results of the N-terminal amino acid sequence analyses, $58 \mathrm{~K}$ protein could be a family of human tyrosine kinase (TXK) (7). TXK is a member of the Tec subfamily of Src type (non-receptor) tyrosine kinases and is reported to be expressed in T cells. Although, the internal amino acid sequence analyses failed to confirm the results in the present experiments, it could be possible that $58 \mathrm{~K}$ protein is a tyrosine kinase since $45 \mathrm{k}-\mathrm{Da}$ tyrosine kinase was detected and purified from hamster spermatozoa (32). Alternatively, $58 \mathrm{~K}$ protein might be a

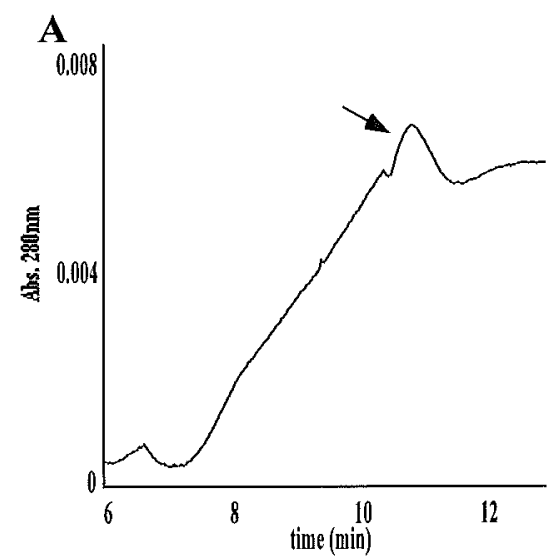

D

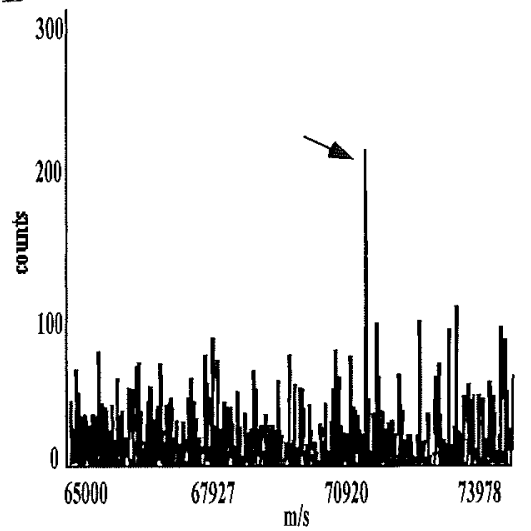

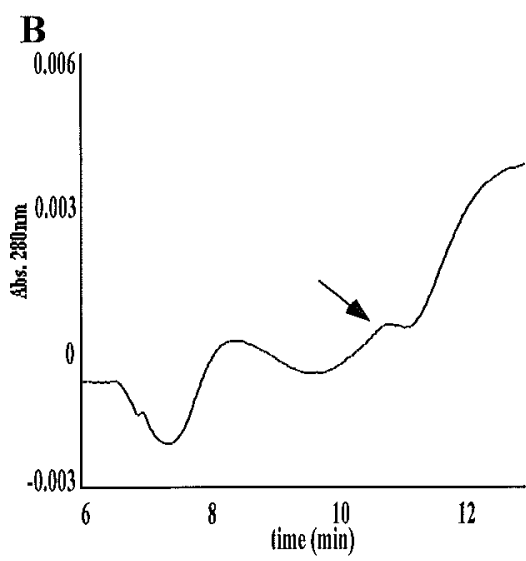

$\mathbf{E}$

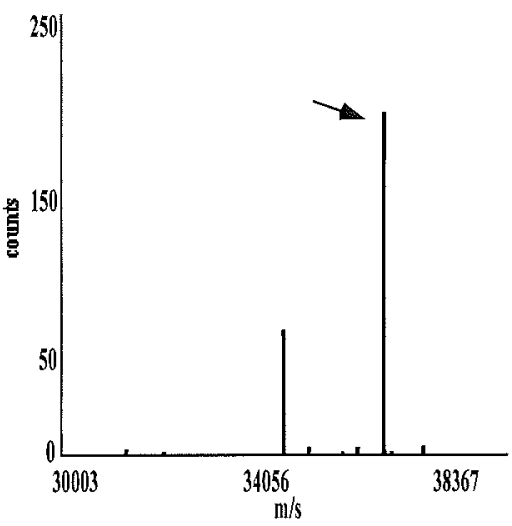

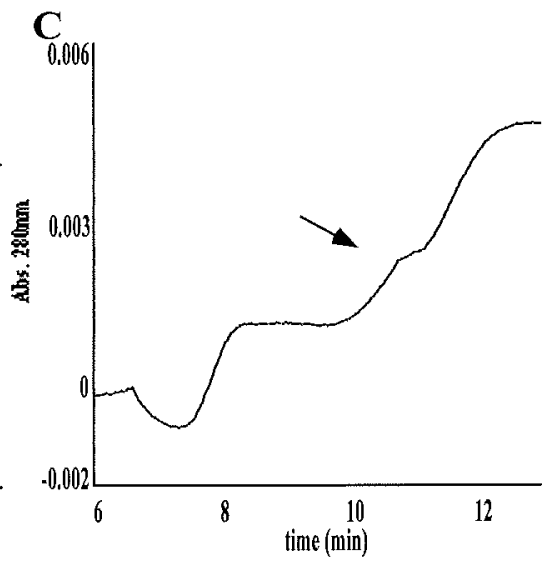

F

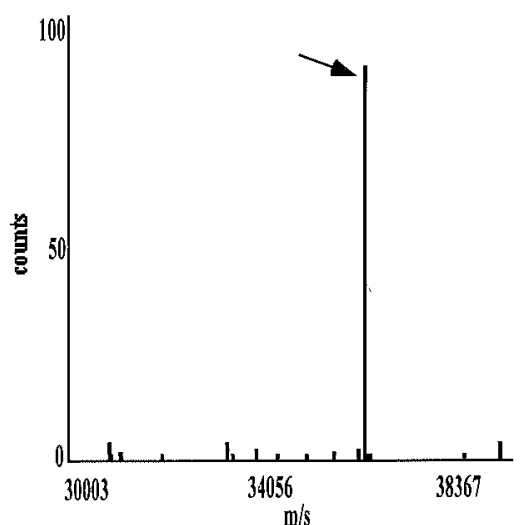

Fig. 8 Inverse gradient reverse phase chromatography and mass spectrometry of $66 \mathrm{~K}$, two types of $36 \mathrm{~K}$ protein. Inverse gradient reverse phase chromatography of $66 \mathrm{~K}$ protein (A), $36 \mathrm{~K}-\mathrm{A}$ protein (B) and $36 \mathrm{~K}-\mathrm{B}$ protein (C) were shown. Gradient of 95\%-50\% n-propanol was carried out. Mass spectrometry of $66 \mathrm{~K}$ protein (D), $36 \mathrm{~K}-\mathrm{A}$ protein $(\mathrm{E})$ and $36 \mathrm{~K}-\mathrm{B}$ protein $(\mathrm{F})$ were shown. Arrow showed peak of each proteins. 
novel protein containing TXK sequence.

Surveyed mass of peptide of fraction 34 from $58 \mathrm{~K}$ protein obtained by in-gel-digestion differed from theoretical mass. Difference between theoretical mass and surveyed mass generally is caused by modification of protein. Therefore, it was likely that $58 \mathrm{~K}$ protein was modified.

It has been widely accepted that motility of spermatozoa is regulated by a single signal pathway (40). In this model, extracellular calcium acts as the first messenger and cAMP as the second messenger. Phosphorylation of $36 \mathrm{~K}-\mathrm{A}$ and $36 \mathrm{~K}-\mathrm{B}$ proteins would be a key reaction in this pathway since phosphorylation of those $36 \mathrm{~K}$ proteins and

A

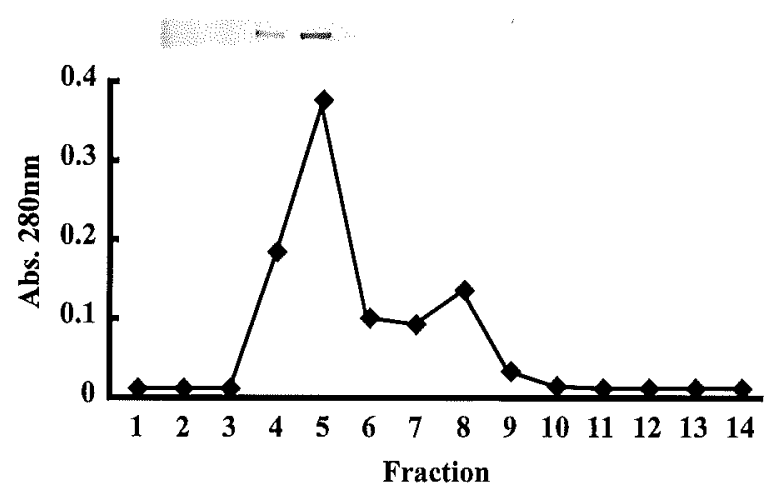

B

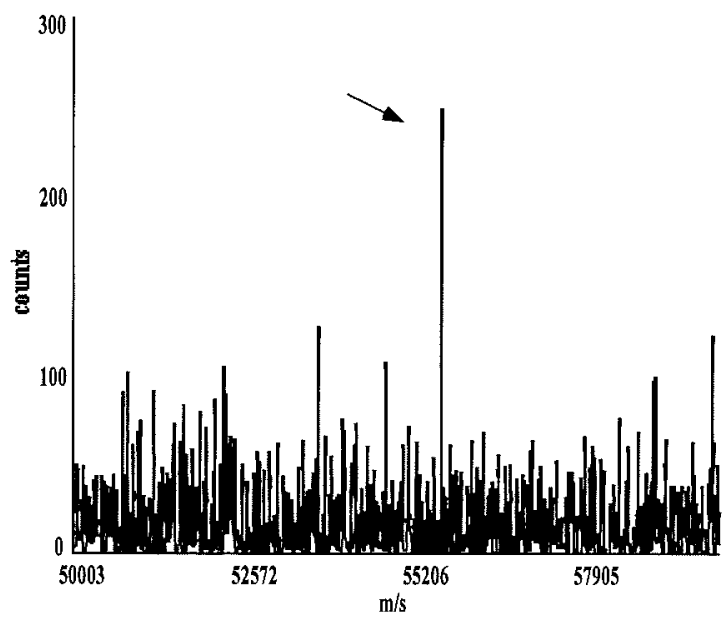

Fig. 9 Desalting and mass spectrometry of $58 \mathrm{~K}$ protein. A: Desalting of $58 \mathrm{~K}$ protein. Graphic chart showed absorbance of $280 \mathrm{~nm}$ against fractions (1 $\mathrm{mL} /$ fraction). Inside photography showed the results of SDS-PAGE against fractions (from No. 2 to No. 9). B: Mass spectrometry of $58 \mathrm{~K}$ protein. Arrow showed peak of $58 \mathrm{~K}$ protein. flagellar activation occurred associating with extracellular calcium and with cAMP (see Fig. 3 and 4). On the other hand, present study suggested that phosphorylation of $66 \mathrm{~K}$ and $58 \mathrm{~K}$ proteins were not included in this pathway since phosphorylation of those proteins occurred independently of extracellular calcium. Therefore, we assume that the presence of a new signal pathway that initiates motility without extracellular calcium. Phosphorylation of $66 \mathrm{~K}$ and $58 \mathrm{~K}$ protein would be involved in this new pathway. Candidates for triggering this new pathway may be a change in intracellular $\mathrm{pH}(1,39)$, or be removal of a motility inhibitor such as inhibin (40) since

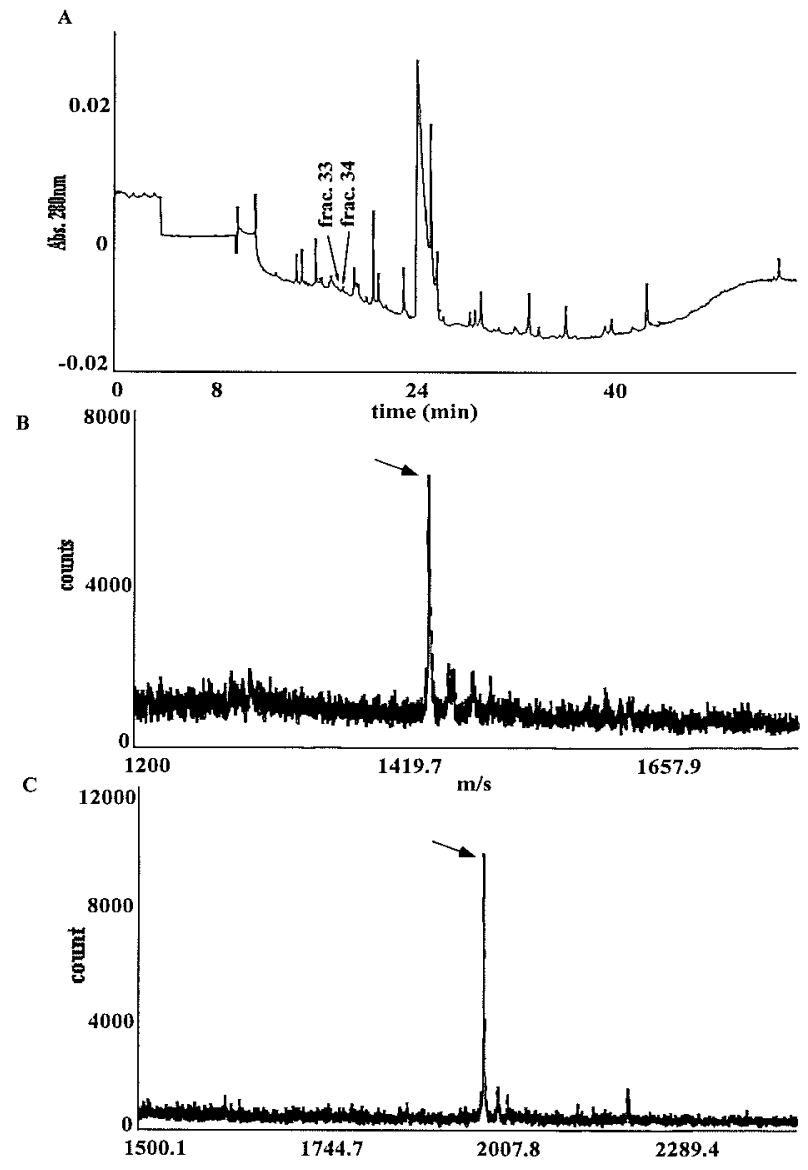

Fig. 10 Protease digestion and mass spectrometry of $58 \mathrm{~K}$ protein. Ai separating of $58 \mathrm{~K}$ protein fragment digested by AP-1 and V8 protease. Gradient of $0-100$ $\%$ acetonitoril and $0.1 \%$ TFA was carried out. Peaks of fraction 33 and 34 were shown by arrow. B: mass spectrometry of fraction 33. C: mass spectrometry of fraction 34. Peptide obtained from $58 \mathrm{~K}$ protein included in fraction 33 and 34 only as single fragment. 


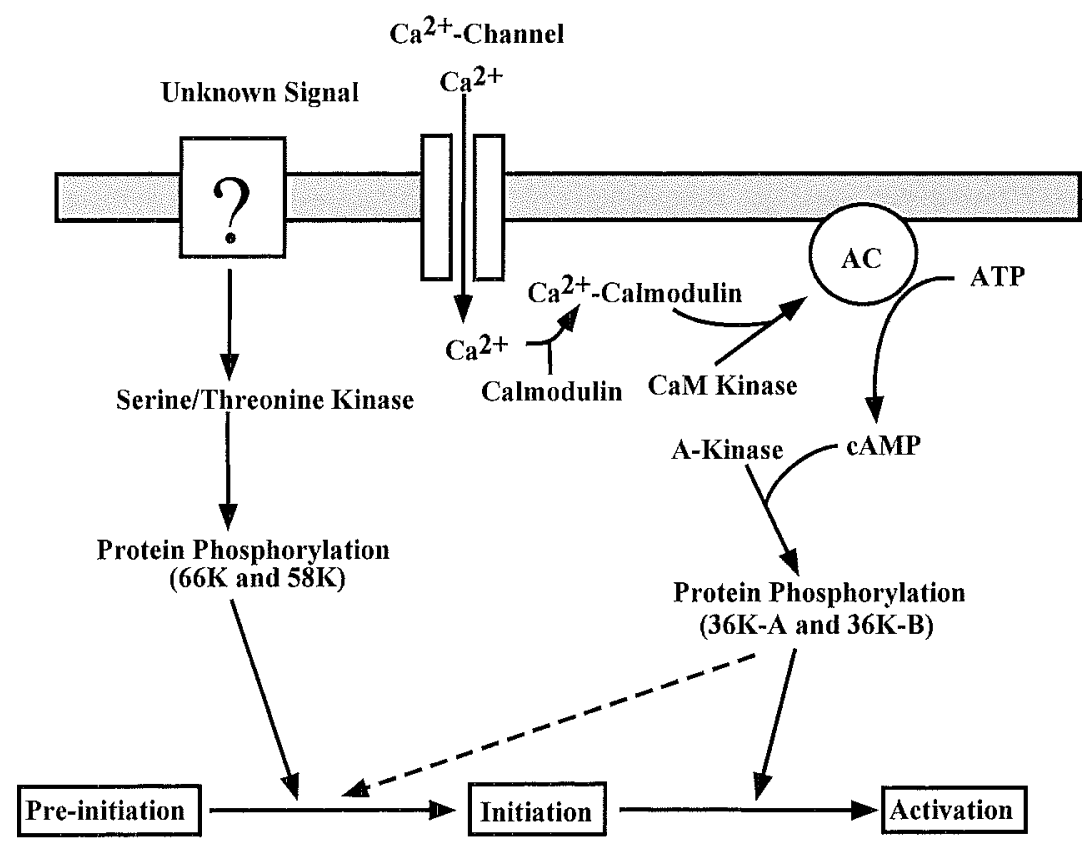

Fig. 11 The hypothesis for the regulatory pathway on activation of spermatozoa motility. It was proposed that the regulatory pathway consisted of two kinds of mechanism. One mechanism was a general scheme that extracellular calcium activated spermatozoa. This scheme also included in phosphorylation of two $36 \mathrm{~K}$ proteins. The other was extracellular calcium independent, but the trigger was not identified yet. The $66 \mathrm{~K}$ protein and $58 \mathrm{~K}$ protein were phosphorylated associated with the initiation of spermatozoa. Since phosphorylation of those was at serine residues, upstream of those proteins in this scheme should be serine/threonine kinase.

both of them should undergo just on dilution of spermatozoa. However, we do not have any evidence yet. Phosphorylation of 36K-B protein may cross talk with this new pathway since it was slightly phosphorylated on motility initiation. On the basis of results obtained from the present experiments and previous studies $(5,16,38,40)$, we would like to propose the scheme for two signal pathways of motility regulation of spermatozoa shown in Fig. 11. One cascade starts flagellar movement. Phosphorylation of $66 \mathrm{~K}$ and $58 \mathrm{~K}$ proteins is involved in the cascade. Another cascade activates motility of the spermatozoa with extracellular calcium via intercellular cAMP. Phosphorylation of $36 \mathrm{~K}-\mathrm{A}$ and $36 \mathrm{~K}-\mathrm{B}$ protein is involved in the cascade. Phosphorylation of $36 \mathrm{~K}-$ $A$ and $36 \mathrm{~K}-\mathrm{B}$ proteins also may cross talk between the two signal pathways.

\section{Acknowledgement}

We thank Dr S. Yamaoka for his kind encouragement, $\mathrm{Dr} \mathrm{T}$. Ishimoda-Takagi and $\mathrm{Dr} \mathrm{M}$. Ikeda for their supports, and Ms K. Yamada, Ms N. Fujinoki and Ms Y. Imaizumi for excellent assistance.

\section{REFERENCES}

1. ABabcock D.F., Rufo Jr G.A. and Lardy H.A. (1983) Potassium-dependent increases in cytosolic $\mathrm{pH}$ stimulate metabolism and motility of mammalian sperm. Proc. Nat. Acad. Sci. USA, 80, 1327-1331.

2. Bradford M.M. (1976) A rapid and sensitive method for the quantitation of microgram quantities of protein utilizing the principle of protein-dye binding. Anal. Biochem., 72. 248-254.

3. Carrera A., Moos J., Ning X.P., Gerton G.L., Tesarik J. and Kopf G.S., Moss S.B. (1996) Regulation of protein tyrosine phosphorylation in human sperm by a calcium/ calmodulin-dependent mechanism: Identification of A kinase anchor proteins as major substrates for tyrosine phosphorylation. Dey. Biol., 180. 284-296.

4. Curry P.T. and Atherton R.W. (1992) Cauda epididymal sperm interactions with seminal vesicle fluid. Mol. Reprod. Dev., 33, 67-73.

5. Eddy E.M. and O'Brien D.A. (1994) The spermatozoon. In The Physiology of Reproduction Vol 1 pp 29-77 Eds K Neill and GM Pfaff. Raven Press, New York,

6. Feng B., Bhattacharyya A. and Yanagimachi R. (1987) $\mathrm{Ca}^{2}+$ is essential for the motility of plasma membrane-intact, but not of demembranated, hamster spermatozoa. Andrologia, 20, 155-162. 
7. Harie R.N., Ohta Y., Lewis J.E., Fu S.M., Kroisel P. and Litman G.W. (1994) TXK, a novel human tyrosine kinase expressed in $\mathrm{T}$ cells shares sequence identity with Tec family kinases and maps to 4pI2. Hum. Mol. Genet., 3, 897-901.

8. Hirabayashi T. (1981) Two-dimensional gel electrophoresis of chicken skeletal muscle proteins with agarose gels in the first dimension. Anal. Biochem., 117. 443-451.

9. Hyne R.V. and Garbers D.L. (1979) Regulation of guinea pig sperm adenylate cyclase by calcium. Biol. Reprod., 21, $1135-1142$.

10. Ishida K., Okuno M., Morisawa S., Mohri T,, Mohri H., Waku M. and Morisawa M. (1987) Initiation of sperm motility induced by cyclic AMP in hamster and boar. Dev. Growth Differ:, 29, 47-56.

11. Kaláb P., Pêknicová J., Geussovâ G. and Moos J. (1998) Regulation of protein tyrosine phosphorylation in boar sperm through a cAMP-dependent pathway. Mol, Reprod. Dev., 51. 304-314.

12. Kawasaki H., Emori Y., Suzuki K. (1990) Production and separation of peptides from proteins stained with Coomassie brilliant blue R-250 after separation by sodium dodecyl sulfate-polyacrylamide gel electrophoresis. Anal. Biochem., 191, 332-336.

13. Laemmli U.K. (1970) Cleavage of structural proteins during assembly of the head of bacteriophage T4. Nature, 227, 680-685.

14. Leclerc P., De Lamirande E. and Gagnon C. (1996) Cyclic adenosine 3, 5' monophosphate-dependent regulation of protein tyrosine phosphorylation in relation to human sperm capacitation and motility. Biol. Reprod., 55, 684692.

15. Lindemann C.B. (1978) A cAMP-induced increase in motility of demembranated bull sperm models. Cell, 13, 918.

16. Lindemann C.B. and Kanous K.S. (1997) A model for flagellar motility. Inte. Rev. Cytol, 173, 1-72.

17. Maleszewski M., Kline D. and Yanagimachi R. (1995) Activation of hamster zona-free oocytes by homologous and heterologous spermatozoa. J. Reprod. Fertil., 105, 99107.

18. Morisawa M. (1994) Cell signaling mechanisms for sperm motility. Zool. Sci, 11, 647-662.

19. Moss S.B., Turner R.M.O., Burkert K.L., Butt H.V. and Gerton G.L. (1999) Conservation and function of a bovine sperm A-kinase anchor protein homologous to mouse AKAP82. Biol. Reprod., 61, 335-342.

20. Okamura N. and Sugita Y. (1983) Activation of spermatozoan adenylate cyclase by a low molecular weight factor in porcine seminal plasma. J. Biol. Chem., 258, 1305613062 .

21. Ramasharma K., Sairam M.R., Seidah N.G., Chretien M., Manjunath P., Schiller P.W., Yamashiro D. and Li C.H. (1984) Isolation, structure, and synthesis of a human seminal plasma peptide with inhibin-like activity. Science, 223, 1199-1202.

22. Si Y. and Okuno M. (1993) Multiple activation of mouse sperm motility. Mol. Reprod. Dev, 36, 89-95.

23. Si Y. and Okuno M. (1995) Activation of mammalian sperm motility by regulation of microtubule sliding via cyclic adenosine 5'-monophosphate-dependent phosphorylation. Biol. Reprod., 53, 1081-1087.

24. Si Y. and Okuno M. (1999) Regulation of microtubule sliding by a $36-\mathrm{kDa}$ phosphoprotein in hamster sperm flagella. Mol. Reprod. Dev, 52, 328-334.

25. Si Y. and Okuno M. (1999) Role of tyrosine phosphorylation of flagellar proteins in hamster sperm hyperactivation. Biol. Reprod., 61, 240-246.

26. Si Y. (1999) Hyperactivation of hamster sperm motility by temperature-dependent tyrosine phosphorylation of an 80-kDa protein. Biol. Reprod., 61, 247-252.

27. Simpson R.J., Moritz R.L., Nice E.E. and Grego B. (1987) A high-performance liquid chromatography procedure for recovering subnanomole amounts of protein from SDS-gel electroeluates for gas-phase sequence analysis. Eur. $J$. Biochem., 165, 21-29.

28. Simpson R.J., Ward L.D., Reid G.E., Batterham M.P. and Mpritz R. L. (1989) Peptide mapping and internal sequencing of proteins electroblotted from two-dimensional gels onto polyvinylidene difluoride membranes. J. Chromatography, 476, 345-361.

29. Tash J.S., Kakar S.S. and Means A.R. (1984) Flagellar motility requires the $\mathrm{CAMP}$-dependent phosphorylation of a heat-stable NP-40-soluble $56 \mathrm{kd}$ protein, axokinin. Cell, 38, 551-559.

30. Tash J.S. and Bracho G.E. (1998) Identification of phosphoproteins coupled to initiation of motility in live epididymal mouse sperm. Biochem. Biophy. Res. Commun., 251, 557-563.

31. Towbin H., Staehelin T. and Gordon J. (1979) Electrophoretic transfer of proteins from polyacrylamide gels to nitrocellulose sheets: procedure and some applications. Proc. Nat. Acad. Sci. USA, 76, 4350-4354.

32. Uma Devi, K., Jha, K., Patil, S. B. Padma, P. and Shivaji, S. (2000) Inhibition of motility of hamster spermatozoa by protein tyrosine kinase inhibitors. Andorologia, 32, 95106.

33. Vesterberg O. (1971) Isoelectric focusing of proteins. In Methods in Enzymology Vol 22, pp399-412 Academic Press, New York.

34. Vijayaraghavan S., Goueli S.A., Davey M.P. and Carr D. W. (1997) Protein kinase A-anchoring inhibitor peptides arrest mammalian sperm motility. J. Biol. Chem. 272, $4747-4752$

35. Visconti P.E., Bailey J.L., Moore G.D., Pan D., OldsClarke P. and Kopf G.S. (1995) Capacitation of mouse spermatozoa. I. Correlation between the capacitation state and protein tyrosine phosphorylation. Development, 121, $1129-1137$.

36. Visconti P. E., Moore G.D., Bailey J.L., Leclerc P., Connors S.A., Pan D., Olds-Clarke P. and Kopf G.S. (1995) Capacitation of mouse spermatozoa. II. Protein tyrosine phosphorylation and capacitation are regulated by a cAMP-dependent pathway. Development, 121, 1149-1150.

37. Visconti P.E., Johnson L.R., Oyaski M., Fornés M., Moss S.B., Gerton G.L. and Kopf G.S. (1997) Regulation, Iocalization, and anchoring of protein kinase $A$ subunits during mouse sperm capacitation. Dev. Biol., 192, 351-363.

38. Visconti P.E. and Kopf G.S. (1998) Regulation of protein phosphorylation during sperm capacitation. Biol. Reprod., 59, $1-6$.

39. Wong P.Y.D., Lee W.M. and Tsang A.Y.F. (1981) The effects of extracellular sodium on acid release and motility initiation in rat caudal epididymal spermatozoa in vitro. Exp. Cell Res., 131, 97-104.

40. Yanagimachi R. (1994) Mammalian fertilization. In The Physiology of Reproduction Vol 1 pp 189-317 Eds K. Neill and G. M. Pfaff. Raven Press, New York. 